\title{
Utilization of agroindustrial residue from passion fruit (Passiflora edulis) seeds as a source of fatty acids and bioactive substances
}

\author{
Orquídea Vasconcelos dos SANTOS ${ }^{1}$ (D), Evelyn Lais Santos VIEIRA ${ }^{1}$, Stephanie Dias SOARES ${ }^{1}$, \\ Leyvison Rafael Vieira da CONCEIÇÃO ${ }^{1}$, Francisco das Chagas Alves do NASCIMENTO', \\ Barbara Elisabeth TEIXEIRA-COSTA ${ }^{2,3 *}$ (it)
}

\begin{abstract}
The aim of this study was to evaluate the properties of the oil extracted from passion fruit seeds (Passiflora edulis), an agroindustrial residue from juice industries, as a potential source of polyunsaturated fatty acids and bioactive substances. The oil presented low levels of free fatty acids and peroxides, as well a great amount of polyunsaturated fatty acids $58.4 \%$, especially linoleic and linolenic acids, which indicates lower oxidation and good source of lipids. A relevant antioxidant activity as a result of a satisfactory content of bioactive substances, such as polyphenols, flavonoids, carotenoids and ascorbic acid, were determined in the passion fruit seed oil. The thermodegradation behavior of the oil suggested high thermal stability and the infrared spectroscopy exhibited high intensity bands between $1745 \mathrm{~cm}^{-1}$ to $1163 \mathrm{~cm}^{-1}$ correlated to the functional groups of fatty acids. Due to their bioactivity and presence of nutritious substances, the passion fruit seed oil may have beneficial properties to health and to extend the shelf-life foods products when present in dietary foods. Furthermore, the use of this by-product could reduce agroindustrial waste, expand and add value to the production chain when used as an industrial lipid matrix.
\end{abstract}

Keywords: passion fruit; seed oil; agroindustrial waste; fatty acids; linoleic acid; bioactive substances.

Practical Application: Utilization of agroindustrial residues to obtainment of an edible oil and bioactive substances.

\section{Introduction}

The passion fruit, Passiflora edulis, has great economic importance in tropical regions, because of its nutritional properties and peculiar flavor/scent. It is estimated that in Brazil $60 \%$ of the cultivation of this fruit is destined for fresh consumption, whilst the rest of its production is used to juices and concentrates processing. P. edulis is commonly cultivated in tropical climates, which purports fast and favorable economic returns. Furthermore, as it is a source of pleasant flavor and aroma, it can be used in numerous products across different industries (Acham et al., 2018; Ramaiya et al., 2018; Santos et al., 2014).

The demand for this fruit has increased in the last years due to its nutritional qualities, which includes a high content of vitamins, phenolic compounds and carotenoids. The latter contribute to the typical yellow color of the fruit and have roles as a functional substance in foods. The passion fruit seeds could be processed as an alternative raw material to obtain a source rich in lipids and essential fatty acids, such as linoleic, oleic and palmitic acids, thus reducing waste from passion fruit processing and generating a new product with prospective health benefits (Acham et al., 2018; Barrales et al., 2015; Claro et al., 2018; Chóez-Guaranda et al., 2017; Ramaiya et al., 2018)

Several researches have evaluated the chemical composition and physicochemical behavior of some agroindustry residues by the application of different technological processes to demonstrate its potentiality as a good source of sustainable products (Acham et al., 2018; Claro et al., 2018; Ganesan et al., 2018; Lei et al., 2018; Matos et al., 2019; Oliveira et al., 2016; Satija \& Hu, 2018; Santos et al., 2018, 2019).

Although the fruit itself already has many purposes, the agroindustrial by-products generated from the processing of the fruit have been little explored as a source of fatty acids. In this context, the oil extracted from passion fruit seeds emerge as a potential material to be used in several technological segments, such as for medicinal purposes or in cosmetics or food. Therefore, this research aimed to extract the oil from the passion fruit seeds and to evaluate the nutritional, functional and antioxidant properties, as well as its thermodegradation behavior and spectroscopic characteristics.

\section{Materials and methods}

\subsection{Raw materials and chemicals}

Approximately $10 \mathrm{~kg}$ of passion fruit seeds as a residue from the production of concentrated juice was provided by a local food industry in the city of Belém, Pará, Brazil. The samples were transported in plastic bags of low-density polyethylene 
and stored under refrigaration until further utilization. The passion fruit seeds were washed with distilled water and dried in an air recirculation oven (510.150 model, Thoth Equipment, SP, Brazil) at $60^{\circ} \mathrm{C}$ until constant weight, and then crushed in a Willey mill (TE-650 model, Tecnal, SP, Brazil).

ABTS (2,2'-azino-bis-3-ethylbenzothiazoline-6sulphonic acid) $(\mathrm{CID}=16240279)$, gallic acid $(\mathrm{CID}=370)$, Trolox (( \pm$)$-6-Hydroxy-2,5,7,8-tetramethylchromane-2-carboxylic acid) and TPTZ (2,4,6-Tri(2-pyridil)-s-triazine) were purchased from Sigma-Aldrich (Milan, Italy). All the other chemicals used in this study were of analytical grade.

\subsection{Extraction, yield and physicochemical quality of the oil}

A solid-liquid extraction was carried out in Soxhlet apparatus to aquire the oil from the P. edulis seeds (PFSO) according to Association of Official Analytical Chemists (2010). The oil extraction and the physicochemical analyses were performed in triplicate.

The general extraction yield was based on the maximum amount of soluble material extracted from a solid matrix under specific temperature, pressure, and time conditions. The extraction yield (\%) was calculated according to Eq. (1).

Yield $=\left(\frac{\mathrm{W}_{\text {oil }}}{\mathrm{W}_{\text {sample }}}\right) \times 100$

where $\mathrm{W}_{\text {oil }}$ is the weight of extracted oil and $\mathrm{W}_{\text {sample }}$ is the total weight of the solid material from P. edulis seeds.

The physicochemical quality of the PFSO, as a source of edible lipids, was determined by its acidity and peroxide values according to the official methods, $\mathrm{Cd} 3 \mathrm{~d}-63$ and $\mathrm{Cd} 8-53$ respectively, from the American Oil Chemists Society (2004).

\subsection{Fatty acids profile}

The profile of fatty acids was established by methyl esterification of fatty acids according to the boron trifluoride (BF3) method in ISO 5509:2000(E) from International Organization for Standardization (2000, pp. 1-6). After phase separation, the supernatant was collected and submitted to gas chromatography analysis according to Milinsk et al. (2008). For this, a gas chromatographer (GC) coupled to microcomputer with the software Galaxie Chromatography was used under the following parameters: fused silica $\mathrm{SP}^{\circledR}-2560$ capillary column (SUPELCO, USA) of $100 \mathrm{~m}$ in length and $0.25 \mathrm{~mm}$ of internal diameter, containing $0.2 \mu \mathrm{m}$ of polyethylene glycol. The operation conditions were: split injection, ratio of $50: 1$; column temperature at $140^{\circ} \mathrm{C}$ for $5 \mathrm{~min}$ programmed with an increasing rate of $4^{\circ} \mathrm{C} \mathrm{min}^{-1}$ up to $240^{\circ} \mathrm{C}$, helium as carrier gas, isobaric pressure of $37 \mathrm{psi}$, linear velocity of $20 \mathrm{~cm} \mathrm{sec}^{-1}$; helium at $29 \mathrm{~mL} \mathrm{~min}^{-1}$ as make-up gas; injector temperature of $250^{\circ} \mathrm{C}$, model Varian CP8410 (Autosampler); detector temperature at $250^{\circ} \mathrm{C}$. The qualitative composition was determined by comparing the time of peak retention with the respective standards for fatty acids. The quantitative composition was determined by area normalization, expressed in mass percentage as established by the Ce 1-62 method (American Oil Chemists Society, 2005).

\subsection{Functional quality of the lipid fractions}

The FAs were classified into fractions according to the presence and number of double or triple bonds: saturated fatty acids (SFA), unsaturated fatty acids (UFA), monounsaturated fatty acids (MUFA) and polyunsaturated fatty acids (PUFA). The functional quality of these fractions was subsequently determined through the following indices. The indices of atherogenicity (AI) and thrombogenicity (TI) were quantified according to Ulbricht, \& Southgate (1991), and the hypocholesterolemic/ hypercholesterolemic ratio $(\mathrm{H} / \mathrm{H})$ was calculated as defined by Santos-Silva et al. (2002). These indices were calculated using the following Eqs. (2), (3) and (4):

$$
\begin{aligned}
& \mathrm{AI}=\frac{\left[\left(\mathrm{C}_{12: 0}+\left(4 \times \mathrm{C}_{14: 0}\right)+\mathrm{C}_{16: 0}\right)\right]}{(\mathrm{PUFA}+\mathrm{MUFA})} \\
& \mathrm{TI}=\frac{\left(\mathrm{C}_{12: 0}+\mathrm{C}_{16: 0}+\mathrm{C}_{18: 0}\right)}{\left[(0.5 \mathrm{X} \text { MUFA })+(0.5 \mathrm{X} \text { n6PUFA })+(3 \mathrm{X} \text { n3PUFA })+\left(\frac{\text { n3PUFA }}{\text { n6PUFA }}\right)\right]} \\
& \mathrm{H} / \mathrm{H}=\frac{\mathrm{C}_{18: 1}+\text { PUFA }}{\left(\mathrm{C}_{14: 0}+\mathrm{C}_{16: 0}\right)}
\end{aligned}
$$

\subsection{Analyses of bioactive compounds of the PFSO}

\section{Total polyphenol content}

The total content of polyphenols from these fractions was analyzed according to the Folin-Ciocalteu assay, as reported by Aliakbarian, Casazza \& Perego (2011), using an UV-Vis spectrophotometer (model UV-1800, Shimadzu, Tokyo, Japan) at $725 \mathrm{~nm}$ of wavelength. The results were calculated based on a gallic acid standard curve using the following regression equation $y=0.0017 x\left(\mathrm{R}^{2}=0.9966\right)$.

\section{Total flavonoids content}

The total flavonoids content was analyzed following the assay reported by Francis (1982), using an UV-Vis spectrophotometer (model UV-1800, Shimadzu, Tokyo, Japan) at a wavelength of $374 \mathrm{~nm}$.

\section{Carotenoids and ascorbic acid content}

The total carotenoids were determined using an UV-Vis spectrophotometer (model UV-1800, Shimadzu, Tokyo, Japan) at a wavelength of $450 \mathrm{~nm}$, according to the methodology of Rodriguez-Amaya (2001). The carotenoid content, expressed as $\beta$-caroten, was calculated using the Eqs. (5) and (6).

$$
X(\mu g)=\frac{A \times V \times 10^{6}}{A_{P E} \times 100}
$$

$\beta$ - caroten $(\mu \mathrm{g} / \mathrm{g})=\frac{\mathrm{X}(\mu \mathrm{g})}{\mathrm{S}(\mathrm{g})}$

Where, $\mathrm{X}(\mu \mathrm{g})$ is the weight of carotenoids, $\mathrm{A}$ is the absorbance at $450 \mathrm{~nm}, \mathrm{~V}$ is the volume $(\mathrm{mL})$ of the solution that gives an absorbance of $A, m_{0}$ is equal the mass of sample $(\mathrm{g}), \mathrm{A}_{\mathrm{PE}}$ is the absorbance $\beta$-carotene in petroleum ether and $S$ is the weight of sample $(\mathrm{g})$. 
The ascorbic acid content (AA) was determined by the reduction of 2,6-dichlorophenol-indophenol (DCFI) compound (Cunha-Santos et al., 2019).

\section{Antioxidant activity}

Ferric reducing antioxidant power

The antioxidant activity of the PFSO was measured as ferric reducing antioxidant potential (FRAP), according to the metodology adapted from Lotito \& Frei (2004). In this method, $10 \mu \mathrm{l}$ of 5\% PFSO diluted in ethanol were mixed in a 96-well plate with $300 \mu$ of FRAP reagent (a solution containing a 10:1:1 mixture of $300 \mathrm{mM}$ sodium acetate $\mathrm{pH}$ 3.6: $0.8 \mathrm{mM}$ TPTZ: $1.7 \mathrm{mM} \mathrm{FeCl}_{3}$ ), and incubated for $15 \mathrm{~min}$ at $37^{\circ} \mathrm{C}$. The absorbance was read at $593 \mathrm{~nm}$ in a plate-reader spectrophotometer (Spark 10M, Tecan Trading AG, Switzerland). Results were compared with a Trolox standard curve and expressed as $\mathrm{mg} / \mathrm{mL}$ of Trolox equivalents (mg $100 \mathrm{~g}^{-1} \mathrm{TE}$ ).

Trolox equivalent antioxidant capacity

The antioxidant capacity of the PFSO was also evaluated as trolox equivalent antioxidant capacity (TEAC), according to the metodology from Re et al. (1999). For this assay, $10 \mu \mathrm{l}$ of $5 \%$ PFSO diluted in ethanol were mixed in a 96-well plate with $300 \mu \mathrm{l}$ ABTS solution. The absorbance was read after $6 \mathrm{~min}$ at $734 \mathrm{~nm}$ using a plate-reader spectrophotometer (Spark 10M, Tecan Trading AG, Switzerland). Results were compared with a Trolox standard curve and expressed as $\mathrm{mg} / \mathrm{mL}$ of Trolox equivalents (mg $100 \mathrm{~g}^{-1} \mathrm{TE}$ ).

\subsection{Infrared spectroscopy (FTIR)}

Fourier transform infrared spectroscopy (FTIR) analyses were carried out using a Perkin Elmer spectrometer, Frontier 98737 model (Waltham, MA, USA) at $25^{\circ} \mathrm{C}$ in the $4000-400 \mathrm{~cm}^{-1}$ wavenumber range. The sample spectra were registered by averaging 20 scans with a resolution of $4 \mathrm{~cm}^{-1}$ in transmission mode.

\subsection{Thermogravimetric Analysis (TGA)}

The TGA was used to investigate the thermal stability of the PFSO and carried out under nitrogen atmosphere on a TA Instrument, model Q-500 (New Castle, DE, USA). Approximately, $10 \mathrm{mg}$ of sample were heated from $25^{\circ} \mathrm{C}$ to $700^{\circ} \mathrm{C}$ at a $10^{\circ} \mathrm{C} \mathrm{min}{ }^{-1}$ rate. The derivative thermogravimetric (DTA) curves were used to measure and compare the peak temperatures.

\subsection{Differential Scanning Calorimetry (DSC)}

The thermal properties of the PFSO was investigated using a DSC Q-1000 calorimetry equipment from TA Instruments (New Castle, DE, USA). A sample of approximately $5.0 \mathrm{mg}$ was sealed in an aluminum pan and subjected to a nitrogen atmosphere at $50 \mathrm{~mL} \mathrm{~min}{ }^{-1}$ flow rate. All measurements were consecutively heated, cooled, and reheated at a temperature range of $-50{ }^{\circ} \mathrm{C}$ to $200{ }^{\circ} \mathrm{C}$. DSC profile was analyzed with the Universal Analysis software version 4.2 (TA instruments, New Castle, DE, USA).

\section{Results and discussions}

\subsection{Yield and physicochemical quality of the oil}

The total lipid content, expressed as oil yield, obtained by solid-liquid extraction with petroleum ether using Soxhlet apparatus was $23 \%$. This result is similar to the value (24\%) found in the seed oil of passion fruit extracted by supercritical fluid by Barrales et al. (2015). Whilst Oliveira et al. (2016) reported a superior oil yield (26\%) in the extraction using the solvent hexane. When compared to the oil yield of soybean seed (20\%), commonly used as a source of edible lipids (Malacrida \& Jorge, 2012), the passion fruit seed can be considered a good source of lipids.

The standards of virgin and refined edible oils are regulated by the Codex Alimentarius based on the determination of its acidity and peroxide values. Acidity and peroxide values of PFSO were $2.6 \pm 0.3 \mathrm{mg} \mathrm{KOH} \mathrm{g}^{-1}$ and $3.4 \pm 1.0 \mathrm{mEq}$ of active oxygen $/ \mathrm{kg}$ of oil, respectively. These results are in accordance with the maximum recommended value, $4 \mathrm{mg} \mathrm{KOH} \mathrm{g}^{-1}$ and $15 \mathrm{mEq}$ active oxygen $\mathrm{kg}^{-1}$ of oils, for crude edible fats and oils (Food and Agriculture Organization of United Nations, 2001). Based on these results, it can be inferred that the PFSO presents low levels of free fatty acids and peroxides, which is an indication of lower lipid oxidation, and therefore a good quality source of lipids.

\subsection{Fatty acids profile}

The fatty acids content of the PFSO are listed in Table 1. The oil revealed significant amounts of UFAs, almost $82 \%$, in which the greatest proportion were PUFAs, $58.4 \%$. The major fatty acids determined were linoleic and oleic acids, $\sim 58 \%$ and $22 \%$, respectively. This result is similar to the values of linoleic $(\sim 54 \%)$ and oleic (25\%) acids, determined in soybean oil by Dorni et al. (2018). In other work, the amounts of linoleic and oleic acids determined in the oil extracted by $n$-hexane from the passion fruit seeds, were $67 \%$ and $17 \%$, respectively (Pereira et al., 2019). Since the amounts of linoleic acid are greater than the oleic acid, this can be considered a positive property of this seed oil. The replacement of SFAs for UFAs in diets have been linked to a reduction in total cholesterol and LDL, which can be beneficial to prevent cardiovascular diseases (Briggs et al., 2017).

Among the SFAs, palmitic acid $\left(\mathrm{C}_{16: 0}\right)$ was determined to have the highest proportion, $13 \%$, an expected result since it is the most predominant fatty acid in plants. The content of $\mathrm{C}_{16: 0}$ determined in the present work is comparable to the values, $11 \%$ and $12 \%$, found by Barrales et al. (2015) in PFSO and Dorni et al. (2018) in soybean oil, respectively. The oil from sunflower seed obtained by supercritical fluid extraction in the studies of Rai et al. (2016) also present certain amount (5 to 7\%) of palmitic acid. Pereira et al. (2019) found $11 \%$ and 3\% of palmitic and stearic acids in passion fruit seed oil. From a nutritional perspective, these results reveal an oil with high quality in the fatty acids profile. In this way, the PFSO could contribute to a healthy diet, since it confers a good supply of essential fatty acids and low content of saturated fatty acids (Ramaiya et al., 2018). 


\subsection{Functional quality of the lipid fractions}

The nutritional quality indices from the lipid fractions of the PFSO is listed in Table 1. The results for the AI, TI and $\mathrm{H} / \mathrm{H}$ were $0.16,0.40$ and 6.03, respectively. Desirable values of AI and TI in the human diets should be as close to zero as possible, as they provide protection against cardiovascular injuries. Whilst the hypocholesterolemic/hypercholesterolemic ratio $(\mathrm{H} / \mathrm{H})$ should be high to provide cardioprotective properties and reduce the risk of atheromatous plaques formation (Pinto et al., 2018). A high $\mathrm{H} / \mathrm{H}$ ratio is related to a higher content of UFAs. These indices are also important due to reported effects of certain oils on the metabolism of lipoproteins (Ganesan et al., 2018; Santos et al., 2019). Other authors studying sapucaia nut oil found similar values of $0.18,0.53$ and 5.36 for $\mathrm{AI}$, TI and $\mathrm{H} / \mathrm{H}$, respectively (Santos et al., 2019).

The composition of FAs is a relevant information to consider when choosing edible oils to food products, since they are related to growth, development, maintenance of several functions in human metabolism and good health. In this way, the nutritional quality of the FAs from PFSO presented in this work is an indication to its utilization as an edible oil to food products and as part of a healthy diet.

\subsection{Analyses of bioactive compounds}

The presence of bioactive substances, such as polyphenols, flavonoids, carotenoids and ascorbic acid, in the PFSO was evaluated and are given in Table 2 . The oil presented $285.85 \mathrm{mg} \mathrm{GAE} \mathrm{g}^{-1}$ as total polyphenols content, which may contribute to a

Table 1. Fatty acids profile from oils from passion fruit seed and soybean.

\begin{tabular}{clcc}
\hline Peaks & \multicolumn{1}{c}{ Fatty acids } & $\begin{array}{c}\text { Passion fruit seed oil } \\
(\%)\end{array}$ & $\begin{array}{c}\text { Soybean oil } \\
(\%)\end{array}$ \\
\hline 1 & Myristic $\left(\mathrm{C}_{14: 0}\right)$ & 0.119 & - \\
2 & Palmitic $\left(\mathrm{C}_{16: 0}\right)$ & 13.272 & $11.7 \pm 0.5$ \\
3 & Palmitoleic $\left(\mathrm{C}_{16: 1} \omega-7\right)$ & 0.263 & - \\
4 & Stearic $\left(\mathrm{C}_{18: 0}\right)$ & 3.699 & $3.9 \pm 0.8$ \\
5 & Oleic $\left(\mathrm{C}_{18: 1}\right.$ Cis $\left.\omega-9\right)$ & 21.777 & $24.7 \pm 2.4$ \\
6 & Linoleic $\left(\mathrm{C}_{18: 2} \mathrm{Cis} \omega-6\right)$ & 57.925 & $54.2 \pm 1.7$ \\
7 & Linolenic $\left(\mathrm{C}_{18: 3} \omega-3\right)$ & 0.254 & $5.2 \pm 0.8$ \\
8 & Arachidonic $\left(\mathrm{C}_{20: 4} \omega-6\right)$ & 0.208 & - \\
9 & Behenic $\left(\mathrm{C}_{22: 0}\right)$ & 1.133 & - \\
10 & Erucic $\left(\mathrm{C}_{22: 1} \omega-9\right)$ & 1.350 & \\
\hline$\sum$ Saturated fatty acids & 18.216 & \\
$\Sigma$ Unsaturated fatty acids & 81.777 & \\
$\Sigma$ Monounsaturated & 23.391 & \\
$\Sigma$ Polyunsaturated & 58.387 & \\
$\Sigma \omega-6$ & 58.133 & \\
$\Sigma$ & 0.254 & \\
Total & & 99.999 &
\end{tabular}

\begin{tabular}{lc}
\multicolumn{1}{c}{ Nutritional quality indices } & Passion fruit seed oil \\
\hline $\mathrm{AI}$ & 0.16 \\
$\mathrm{TI}$ & 0.40 \\
$\mathrm{H} / \mathrm{H}$ & 6.03
\end{tabular}

${ }^{\star}$ Dorni et al. (2018). - Not detected or not informed. AI: atherogenicity index, TI: thrombogenicity index and $\mathrm{H} / \mathrm{H}=\Sigma$ hypocholesterolemic/ $\Sigma$ hypercholesterolemic ratio. high antioxidant activity (Moreira-Araújo et al., 2019). This result is slightly inferior to the values, $313 \pm 18 \mathrm{mg} \mathrm{GAEg}^{-1}$, determined from fresh passion fruit seed (Santos et al., 2014). Whereas the flavonoid content determined in the present work, $78.3 \pm 0.5 \mathrm{mg} 100 \mathrm{~g}^{-1}$, is similar to the value $\left(71.8 \mathrm{mg} 100 \mathrm{~g} \mathrm{~g}^{-1}\right)$ found by Santos et al. (2014). These data show the antioxidant capacity of the PFSO as a possible additive to prevent oxidative processes into food matrix.

The PFSO presented $\sim 3 \mu \mathrm{g} 100 \mathrm{~g}^{-1}$ of carotenoids. A classification level was proposed by Matos et al. (2019), in which the carotenoids content is divided in 4 levels as follows: low $\left(0-100 \mu \mathrm{g} 100 \mathrm{~g}^{-1}\right)$, moderate $\left(100-500 \mu \mathrm{g} 100 \mathrm{~g}^{-1}\right)$, high (500 - $\left.2000 \mu \mathrm{g} 100 \mathrm{~g}^{-1}\right)$ and very high $\left(\geq 2000 \mu \mathrm{g} 100 \mathrm{~g}^{-1}\right)$. In another study with PFSO, Silva \& Jorge (2017) determined a higher carotenoid content $\left(6.7 \mu \mathrm{g} \mathrm{g}^{-1}\right)$ compared to the value determined in the present work. A moderate content of ascorbic acid, $0.6 \mathrm{mg} 100 \mathrm{~g}^{-1}$, was also found at the present work when compared to other tropical fruits such as, Platonia insignis

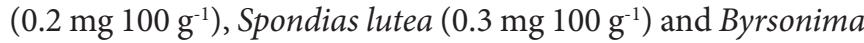
crassifolia (0.3 mg $100 \mathrm{~g}^{-1}$ ) (Canuto et al., 2010). Thus, this oil is a source of carotenoids and ascorbic acid with potential contribution to health maintenance due to its considerable levels of pro-vitamin A and vitamin C.

The antioxidant activity as FRAP assay is a method that measures the increase in absorbance $(593 \mathrm{~nm}$ ) promoted by the reduction of ferric ion $(\mathrm{Fe} 3+)$-ligand to the blue coloured ferrous $(\mathrm{Fe} 2+)$ complexes caused by antioxidants in acidic media (Lotito \& Frei, 2004). The TEAC assay is a method based on the scavenging capacity of antioxidants to radical ABTS ${ }^{+}$, which cause quenching of the blue-green colour proportional to their concentration in the media (Re et al., 1999). Futhermore, the TEAC assay may be used to evaluate the antioxidant capacity of lipophilic substances, such as vegetable oils, because of the ABTS radical solubility in organic solvents, allowing the estimation of antioxidants in it (Castelo-Branco \& Torres, 2012).

The antioxidant capacity of the PFSO are listed in Table 2. As determined in this study and as reported in the literature (Pereira et al., 2019), the oil from passion fruit seed presented several bioactive compounds, such as carotenoids, some phenolic compounds like caffeic, $p$-coumaric and salicylic acids and phytosterols. These substances exhibit antioxidant properties, which plays an important role in the oxidative stability of foods and could be correlated to the antioxidant capacity determined in the PFSO. Pereira et al. (2019) determined the antioxidant activity of the passion fruit seed oil extracted with $n$-hexane by DPPH radical scavenging assay and found a value of $\sim 54 \%$.

Table 2. Content of bioactive substances in the passion fruit seed oil.

\begin{tabular}{|c|c|}
\hline Bioactive substances & Passion fruit seed oil \\
\hline Total polyphenols (mg GAE g $\mathrm{g}^{-1}$ ) & $286 \pm 5$ \\
\hline Flavonoids (mg $100^{-1} \mathrm{~g}$ ) & $78.3 \pm 0.5$ \\
\hline Carotenoids $\left(\mu \mathrm{g} 100 \mathrm{~g}^{-1}\right)$ & $2.9 \pm 0.1$ \\
\hline Ascorbic acid (mg $\left.100 \mathrm{~g}^{-1}\right)$ & $0.6 \pm 0.2$ \\
\hline Antioxidant activity - FRAP (mg $\left.100 \mathrm{~g}^{-1} \mathrm{TE}\right)$ & $0.101 \pm 0.007$ \\
\hline Antioxidant activity - TEAC (mg $\left.100 \mathrm{~g}^{-1} \mathrm{TE}\right)$ & $0.060 \pm 0.002$ \\
\hline
\end{tabular}


In the studies of the TEAC antioxidant capacity assay from different vegetable oils by Castelo-Branco \& Torres (2012), nonsignificant differences $(\mathrm{p}<0.05)$ were observed between the methanolic extracts from soybean (2.1 - 3.1 mmol of TE $/ \mathrm{kg}$ ) and canola oils (1.0 - $3.3 \mathrm{mmol}$ of TE/kg), but these differ from corn $(0.6 \mathrm{mmol}$ of TE$/ \mathrm{kg})$ and sunflower $(0.2-0.5 \mathrm{mmol}$ of TE $/ \mathrm{kg})$ oils. Disagreements between results from literature and the present work may be attibuted to differences in protocols of samples and standards preparation. In Castelo-Branco \& Torres (2012) protocol, the trolox standard and the oil samples were dissolved in hexane. In contrast, the PFSO and Trolox standard were diluted in ethanol and ABTS solution was prepared in ultra-pure water.

\subsection{Infrared spectroscopy (FTIR)}

The FTIR spectrum of the PFSO is shown in Figure 1. Infrared spectroscopy enables the correlation of functional groups to chemical substances through their spectral bands
(Lerma-García et al., 2010). The assignment of bands was associated to their chemical functional groups according to the literature. High intensity bands identified in the range of $3009 \mathrm{~cm}^{-1}$ to $2854 \mathrm{~cm}^{-1}$ were related to the functional groups typically of carboxylic acids, amines, primary and secondary amides. Bands between $1745 \mathrm{~cm}^{-1}$ to $1163 \mathrm{~cm}^{-1}$ are characterized as carbonyl groups, methyl esters, ketones and aldehydes, frequently related to long-chain fatty acids (Lei et al., 2018; Lerma-García et al., 2010; Rohman \& Man, 2010).

\subsection{Thermogravimetric analysis}

The thermogravimetric (TG) and differential thermogravimetric (DTA) curves of the PFSO are illustrated in Figure 2. The thermal degradation curve shows an initial degradation temperature $\left(\mathrm{T}_{\text {onset }}\right)$ at $345.2^{\circ} \mathrm{C}$. The total mass loss detected was $40.2 \%$, indicating the presence of large amounts of inorganic matter in the oil, which remains as residues or ashes at $700{ }^{\circ} \mathrm{C}$. The response observed

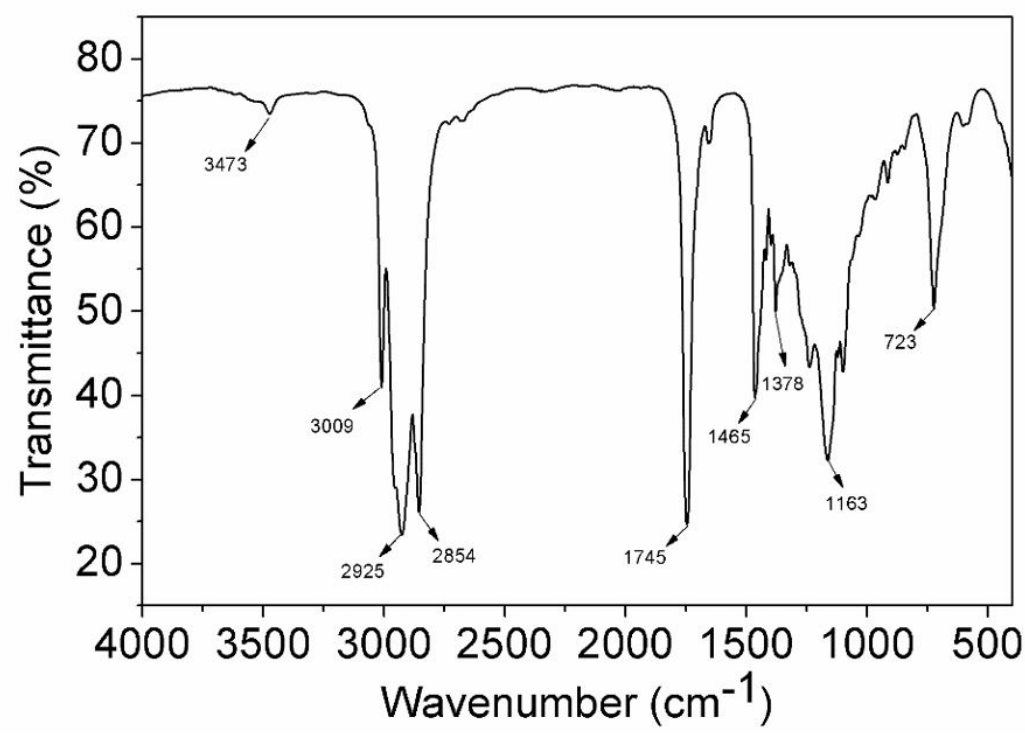

Figure 1. FTIR spectrum of the passion fruit seed oil.

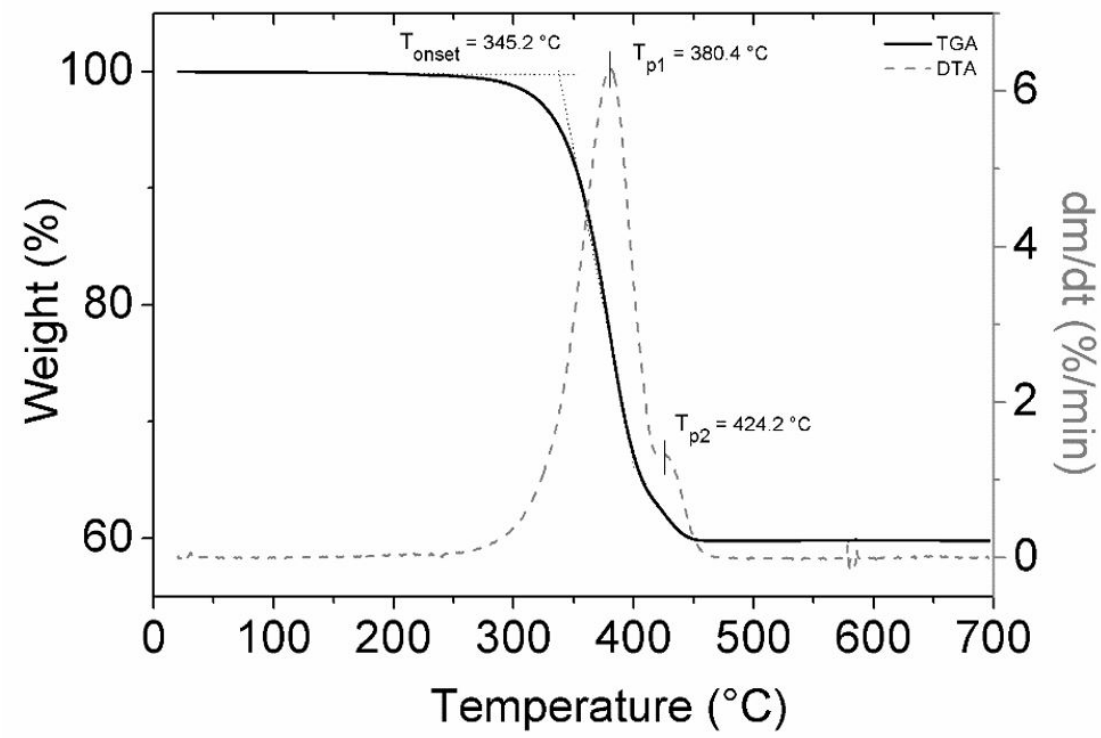

Figure 2. TGA and DTA curves of the passion fruit seed oil. 


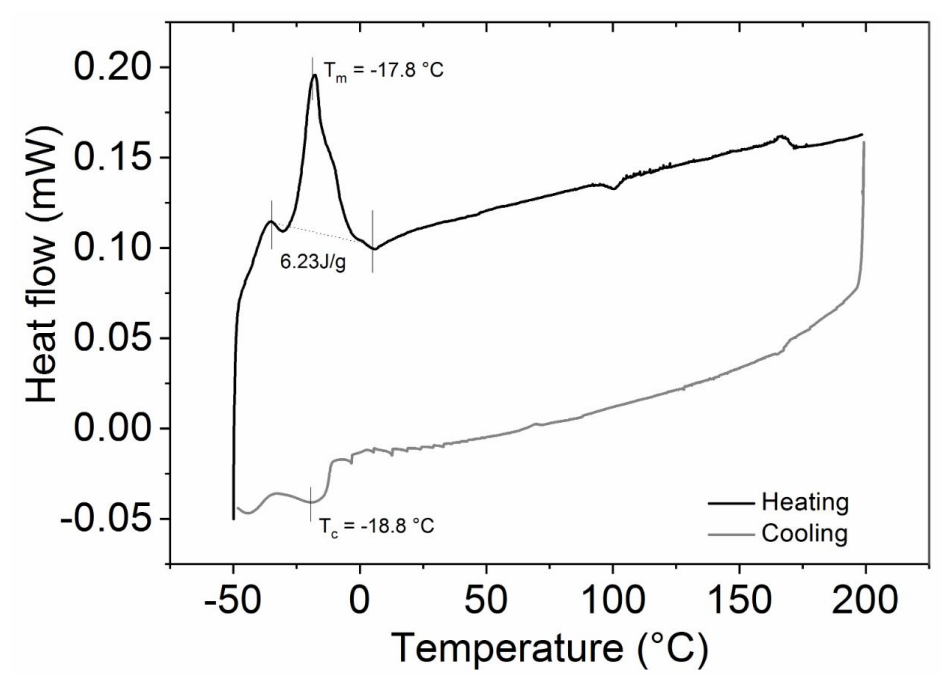

Figure 3. Differential scanning calorimetry curves of the passion fruit seed oil.

in DTA comprises one exothermal peak at $380.4^{\circ} \mathrm{C}$, typically from energy liberation. Chacón-Fernández et al. (2019) found in tamarind seed oil a maximum decomposition temperature at $\sim 418^{\circ} \mathrm{C}$. For these authors, the range between $224-510{ }^{\circ} \mathrm{C}$ correspond to the decomposition of the constituent acylglycerols of the oil. These patterns are associated to the organic matter oxidation by the main agents of thermal $\left({ }^{\circ} \mathrm{C}\right)$ and oxidative $\left(\mathrm{O}_{2}\right)$ degradation. It may be inferred then that the $\mathrm{T}_{\text {onset }}$ occurs far beyond the usual working temperatures for industrial processing $\left(180^{\circ} \mathrm{C}\right)$, meaning this oil could be used as a matrix or an additive in formulations or processes.

\subsection{Differential Scanning Calorimetry (DSC)}

The DSC analysis was performed to evaluate the melting and crystallization behavior of the PFSO. This behavior reflects the complexity of the fatty acid and triglyceride composition in the oil. The DSC curves of the oil are shown in Figure 3. One endothermic peak round $-19^{\circ} \mathrm{C}$ was detected in the cooling curve. This could be related to crystallization of polyunsaturated fatty acids, such as linoleic acid, which is the major fatty acid in this oil. Chacón-Fernández et al. (2019) found in tamarind seed oil that the crystallization occurs between $20.16^{\circ} \mathrm{C}$ and $-38.2^{\circ} \mathrm{C}$. The heating curve showed a large exothermic peak at $-18^{\circ} \mathrm{C}$ reaching $6.2 \mathrm{~J} \mathrm{~g}^{-1}$. This result was similar to the onset melting temperatures of tamarind seed oil was $-22.2^{\circ} \mathrm{C}$ (Chacón-Fernández et al., 2019). Due to the high content of polyunsaturated fatty acids in the PFSO, the crystallization and melting temperatures are very low, which gives this oil a liquid characteristic at room temperature $\left(25^{\circ} \mathrm{C}\right)$.

\section{Conclusion}

The characterization of the oil extracted from the passion fruit (Passiflora edulis) seeds, an agroindustrial residue from juice industries, as a source of fatty acids and bioactive substances was accomplished in the present study. The oil presented low levels of free fatty acids and peroxides, which is an indication of lower lipid oxidation, and therefore a good quality source of lipids. A great amount of polyunsaturated fatty acids, especially omega 6 and 9, as well a relevant content of bioactive substances, such as polyphenols, flavonoids, carotenoids and ascorbic acid, were determined in the seed oil from passion fruit. Due to their bioactivity and nutritious substances, the passion fruit seed oil may have beneficial properties to health, to extend the shelf-life foods products when added into it or used as a lipid matrix for several industries. Furthermore, the use of this by-product could reduce industrial waste and expand the production chain, further adding value to it.

\section{Acknowledgements}

The authors are grateful to Federal University of Rio de Janeiro (Brazil) and University of Leeds (United Kingdom) for providing access to facilities.

\section{References}

Acham, I. O., Ahemen, S., Ukeyima, M. T., \& Girgih, A. T. (2018). Tropical fruits: Bioactive properties and health promoting benefits in chronic disease prevention and management. Asian Food Science Journal, 3(1), 1-13. http://dx.doi.org/10.9734/AFSJ/2018/41853.

Aliakbarian, B., Casazza, A. A., \& Perego, P. (2011). Valorization of olive oil solid waste using high pressure-high temperature reactor. Food Chemistry, 128(3), 704-710. http://dx.doi.org/10.1016/j. foodchem.2011.03.092.

Association of Official Analytical Chemists - AOAC. (2010). Official methods of analysis of the Association of Official Analytical Chemist (Method 948.22). Arlington: AOAC International.

American Oil Chemists Society - AOCS. (2004). Official methods of analysis of the American Oil Chemists Society (Official method Cd3d-63 and Cd 8-53). Urbana, IL: AOCS.

American Oil Chemists Society - AOCS. (2005). Official methods of analysis of the American Oil Chemists Society (Official method Ce 1-62). Urbana, IL: AOCS.

Barrales, F. M., Rezende, C. A., \& Martínez, J. (2015). Supercritical $\mathrm{CO}_{2}$ extraction of passion fruit (Passiflora edulis sp.) seed oil assisted by 
ultrasound. The Journal of Supercritical Fluids, 104, 183-192. http:// dx.doi.org/10.1016/j.supflu.2015.06.006.

Briggs, M., Petersen, K., \& Kris-Etherton, P. (2017). Saturated fatty acids and cardiovascular disease: replacements for saturated fat to reduce cardiovascular risk. Health Care, 5(2), 1-29. PMid:28635680.

Canuto, G. A. B., Xavier, A. A. O., Neves, L. C., \& Benassi, M. T. (2010). Physicochemical characterization of Amazonian fruit pulp and its correlation with free anti-radical activity. Revista Brasileira de Fruticultura, 32(4), 1196-1205. http://dx.doi.org/10.1590/S010029452010005000122.

Castelo-Branco, V. N., \& Torres, A. G. (2012). Generalized linear model describes determinants of total antioxidant capacity of refined vegetable oils. European Journal of Lipid Science and Technology, 114(3), 332-342. http://dx.doi.org/10.1002/ejlt.201100181.

Chacón-Fernández, M. G., Hernández-Medel, M. R., Bernal-González, M., Durán-Domínguez-de-Bazúa, M. C., \& Solís-Fuentes, J. A. (2019). Composition, properties, stability and thermal behavior of tamarind (Tamarindus indica) seed oil. Grasas y Aceites, 70(4), 333. http://dx.doi.org/10.3989/gya.0928182.

Chóez-Guaranda, I., Ortega, A., Miranda, M., \& Manzano, P. (2017). Chemical composition of essential oils of Passiflora edulis f. flavicarpa agroindustrial waste. Emirates Journal of Food and Agriculture, 29, 458-462. http://dx.doi.org/10.9755/ejfa.2016-10-1542.

Claro, M. L., Rodrigues, G. P., \& Teixeira, S. A. (2018). Functional properties of yellow passion fruit bark (Passiflora edulis) in metabolic syndrome. Demetra: Food. Nutrition and Health (Berkhamsted, Hertfordshire), 13, 181-194.

Cunha-Santos, E. C. E., Viganó, J., Neves, D. A., Martínez, J., \& Godoy, H. T. (2019). Vitamin C in camu-camu [Myrciaria dubia (H.B.K.) McVaugh]: evaluation of extraction and analytical methods. Food Research International, 115, 160-166. http://dx.doi.org/10.1016/j. foodres.2018.08.031. PMid:30599928.

Dorni, C., Sharma, P., Saikia, G., \& Longvah, T. (2018). Fatty acid profile of edible oils and fats consumed in India. Food Chemistry, 238, 9-15. http://dx.doi.org/10.1016/j.foodchem.2017.05.072. PMid:28867107.

Food and Agriculture Organization of United Nations - FAO. (2001). Codex Alimentarius: codex standards for fats and oils. Codex Stand 210-1999 (2nd ed). Rome: FAO. Retrieved from http://www.fao. org/3/y2774e/y2774e03.htm\#bm3/

Francis, F. J. (1982). Analysis of anthocyanins. In P. Markakis (Ed.), Anthocyanins as food colors (Chap. 7, p. 181-207). New York: Academic Press. http://dx.doi.org/10.1016/B978-0-12-472550-8.50011-1.

Ganesan, K., Sukalingam, K., \& Xu, B. (2018). Impact of consumption and cooking manners of vegetable oils on cardiovascular diseases - a critical review. Trends in Food Science \& Technology, 71, 132-154. http://dx.doi.org/10.1016/j.tifs.2017.11.003.

International Organization for Standardization - ISO. (2000). ISO 5509:2000(E) animal and vegetable fats and oils: preparation of methyl esters of fatty acids (2nd ed.). London: ISO.

Lei, M., Jiang, F., Cai, J., Hu, S., Zhou, R., Liu, G., Wang, Y. H., Wang, H. B., He, J. R., \& Xiong, X. G. (2018). Facile microencapsulation of olive oil in porous starch granules: Fabrication, characterization, and oxidative stability. International Journal of Biological Macromolecules, 111, 755-761. http://dx.doi.org/10.1016/j.ijbiomac.2018.01.051. PMid:29329810.

Lerma-García, M. J., Ramis-Ramos, G., Herrero-Martínez, J. M., \& Simó-Alfonso, E. F. (2010). Authentication of extra virgin olive oils by Fourier-transform infrared spectroscopy. Food Chemistry, 118(1), 78-83. http://dx.doi.org/10.1016/j.foodchem.2009.04.092.
Lotito, S. B., \& Frei, B. (2004). The increase in human plasma antioxidant capacity after apple consumption is due to the metabolic effect of fructose on urate, not apple-derived antioxidant flavonoids. Free Radical Biology \& Medicine, 37(2), 251-258. http://dx.doi.org/10.1016/j. freeradbiomed.2004.04.019. PMid:15203196.

Malacrida, C. R., \& Jorge, N. (2012). Yellow passion fruit seed oil (Passiflora edulis f. flavicarpa): physical and chemical characteristics. Brazilian Archives of Biology and Technology, 55(1), 127-134. http:// dx.doi.org/10.1590/S1516-89132012000100016.

Matos, K. A. N., Lima, D. P., Barbosa, A. P. P., Mercadante, A. Z., \& Chisté, R. C. (2019). Peels of tucumã (Astrocaryum vulgare) and peach palm (Bactris gasipaes) are by-products classified as very high carotenoid sources. Food Chemistry, 272, 216-221. http://dx.doi. org/10.1016/j.foodchem.2018.08.053. PMid:30309535.

Milinsk, M. C., Matsushita, M., Visentainer, J. V., Oliveira, C. C., \& Souza, N. E. (2008). Comparative analysis of esterification methods in the quantitative determination of vegetable oil fatty acid methyl esters (FAME). Journal of the Brazilian Chemical Society, 19(8), 1475-1483. http://dx.doi.org/10.1590/S0103-50532008000800006.

Moreira-Araújo, R. S. R., Barros, N. V. A., Porto, R. G. C. L., Brandão, A. C. A. S., Lima, A., \& Fett, R. (2019). Bioactive compounds and antioxidant activity three fruit species from the Brazilian Cerrado. Revista Brasileira de Fruticultura, 41(3), e-011. http://dx.doi. org/10.1590/0100-29452019011.

Oliveira, D. A., Angonese, M., Gomes, C., \& Ferreira, S. R. S. (2016). Valorization of passion fruit (Passiflora edulis sp.) by-products: sustainable recovery and biological activities. The Journal of Supercritical Fluids, 111, 55-62. http://dx.doi.org/10.1016/j. supflu.2016.01.010.

Pereira, M. G., Maciel, G. M., Haminiuk, C. W. I., Bach, F., Hamerski, F., de Paula Scheer, A., \& Corazza, M. L. (2019). Effect of extraction process on composition, antioxidant and antibacterial activity of oil from yellow passion fruit (Passiflora edulis Var. Flavicarpa) seeds. Waste and Biomass Valorization, 10(9), 2611-2625. http://dx.doi. org/10.1007/s12649-018-0269-y.

Pinto, R. H. H., Sena, C., Santos, O. V., Costa, W. A., Rodrigues, A. M. C., \& Carvalho, R. N. Jr. (2018). Extraction of bacaba (Oenocarpus bacaba) oil with supercritical $\mathrm{CO}_{2}$ : Global yield isotherms, fatty acid composition, functional quality, oxidative stability, spectroscopic profile and antioxidant activity. Grasas y Aceites, 69(2), 246. http:// dx.doi.org/10.3989/gya.0883171.

Rai, A., Mohanty, B., \& Bhargava, R. (2016). Supercritical extraction of sunflower oil: a central composite design for extraction variables. Food Chemistry, 192, 647-659. http://dx.doi.org/10.1016/j. foodchem.2015.07.070. PMid:26304395.

Ramaiya, S. D., Bujang, J. S., \& Zakaria, M. H. (2018). Nutritive values of passion fruit (Passiflora species) seeds and its role in human health. Journal of Agriculture Food and Development, 4(1), 23-30. http:// dx.doi.org/10.30635/2415-0142.2018.04.4.

Re, R., Pellegrini, N., Proteggente, A., Pannala, A., Yang, M., \& RiceEvans, C. (1999). Antioxidant activity applying an improved ABTS radical cation decolorization assay. Free Radical Biology \& Medicine, 26(9-10), 1231-1237. http://dx.doi.org/10.1016/S0891-5849(98)003153. PMid:10381194.

Rodriguez-Amaya, D. B. A. (2001). A guide to carotenoid analysis in foods (Chap. 8). Washington: International Life Sciences Institute.

Rohman, A., \& Man, Y. B. C. (2010). Fourier transform infrared (FTIR) spectroscopy for analysis of extra virgin olive oil adulterated with palm oil. Food Research International, 43(3), 886-892. http://dx.doi. org/10.1016/j.foodres.2009.12.006. 
Santos, O. V., Carvalho, R. N. Jr., Costa, C. E. F., \& Lannes, S. C. S. (2019). Chemical, chromatographic-functional, thermogravimetricdifferential and spectroscopic parameters of the sapucaia oil obtained by different extraction methods. Industrial Crops and Products, 132, 487-496. http://dx.doi.org/10.1016/j.indcrop.2019.02.043.

Santos, O. V., Correa, N. C. F., Carvalho, R. C., Costa, C. E. F., Moraes, J. F. C., \& Lannes, S. C. S. (2018). Quality parameters and thermogravimetric and oxidative profile of Muruci oil (Byrsonima crassifolia L.) obtained by supercritical $\mathrm{CO}_{2}$. Food Science and Technology (Campinas), 38(1), 172-179. http://dx.doi.org/10.1590/1678-457x.30616.

Santos, V. J., Biondo, P. B. F., Rotta, E. M., Morais, D. R., \& Visentainer, J. V. (2014). Drying Optimization by evaluating the antioxidant activity of waste (seed/ peel) of passion fruit. Braziliam Journal of Food Research, 5(2), 10-16. http://dx.doi.org/10.14685/rebrapa. v5i2.161.
Santos-Silva, J., Bessa, R. J. B., \& Santos-Silva, F. (2002). Effect of genotype, feeding system and slaughter weigt on the quality of light lambs. II. Fatty acid composition of meat. Livestock Production Science, 77(2-3), 187-194. http://dx.doi.org/10.1016/ S0301-6226(02)00059-3.

Satija, A., \& Hu, F. B. (2018). Plant-based diets and cardiovascular health. Trends in Cardiovascular Medicine, 28(7), 437-441. http:// dx.doi.org/10.1016/j.tcm.2018.02.004. PMid:29496410.

Silva, A. C., \& Jorge, N. (2017). Bioactive compounds of oils extracted from fruits seeds obtained from agroindustrial waste. European Journal of Lipid Science and Technology, 119(4), 1-5. http://dx.doi. org/10.1002/ejlt.201600024.

Ulbricht, T. L. V., \& Southgate, D. A. T. (1991). Coronary heart disease: seven dietary factors. Lancet, 338(8773), 8773985-8773992. http:// dx.doi.org/10.1016/0140-6736(91)91846-M. PMid:1681350. 